\title{
Effect of Castor Based Intercropping Systems on Yields and Economics of Castor (Ricinus communis L.)
}

\author{
Mohammed Mohsin ${ }^{1 *}$, J.S. Yadav ${ }^{2}$, Harender ${ }^{1}$ and Naveen Rathi ${ }^{1}$ \\ ${ }^{1}$ Department of Agronomy, CCS Haryana Agricultural University, Hisar-125004, \\ Haryana, India \\ ${ }^{2}$ Department of Agronomy, Regional Research Station, Bawal-123501, Haryana, India \\ *Corresponding author
}

\begin{abstract}
A B S T R A C T
Keywords

Castor, Intercropping, Rowspacing, Castor equivalent yield, Net return and $\mathrm{B}: \mathrm{C}$ ratio

\section{Article Info}

Accepted: 24September 2018 Available Online: 10October2018

A field experiment was conducted at Regional Research Station, Bawal, Haryana during 2015-16 on loamy sand soil under irrigated condition to find out suitable intercrops viz., greengram, groundnut, clusterbean and sesamum under three different row spacings of castor 120, 180 and $240 \mathrm{~cm}$. Results revealed that oil content of castor was not affected by different intercropping systems and row spacing of castor. The mean seed yield of sole castor $(120 \mathrm{~cm})$ was $5246 \mathrm{~kg} \mathrm{ha}^{-1}$, which was more than rest of the treatments. Results showed that magnitude of reduction in seed yield of castor was more severe with sesamum followed by clusterbean. Significantly highest castor equivalent yield $\left(6037 \mathrm{~kg} \mathrm{ha}^{-1}\right)$ was obtained in castor $(180 \mathrm{~cm})+$ groundnut $(1: 4)$, closely followed by castor $(240 \mathrm{~cm})+$ greengram (1:2) intercropping system. Net returns was greater when castor was intercropped with greengram either in 1:6 (Rs. $121455 \mathrm{ha}^{-1}$ ) or 1:2 (Rs. $119986 \mathrm{ha}^{-1}$ ) row proportion. The benefit: cost ratio was highest with castor $(240 \mathrm{~cm})+$ greengram in 1:6 row proportion $(1.79)$ and castor $(180 \mathrm{~cm})+$ greengram in 1:2 row proportion $(1.75)$.
\end{abstract}

\section{Introduction}

Castor (Ricinus communis L.) is an important non edible oilseed crop widely grown in arid and semiarid region. India is the largest producer of castor in the world. It earns valuable forex of worth Rs. 8000 crores and plays an important role in the agricultural economy of the country. Castor oil is mainly used for the manufacture of wide range of ever expanding industrial products such as nylon fibers, jet engine lubricants, hydraulic fluids, cosmetics, pharmaceuticals. Castor (Ricinus communis L.) is an important non edible oil seed crop of India being cultivated in 1.09 million hectares with a production of 1.86 million tonnes In Haryana castor occupies 3 thousand hectares with production of 4 thousand tonnes (Anonymous 2015). The basic concept of intercropping systems involve growing together two or more crops with the assumptions that two crops could exploit the environment better than one and ultimately producing higher yields, the reason being that the component crops differ in resources use and if growing together, they complement each other and make better overall use of resources. This practice leads to 
some advantages like, economy of land, insurance against aberrant weather, production of higher yields and higher economic returns, build up or maintenance of soil fertility and diversification of farm produce. Intercropping provides substantial yield advantage over sole crop owing to temporal and spatial complementarity and minimizing inter or intra specific competition.

Initially it is sluggish in growth, this encourages weed growth which compete with the available resources. Taking advantage of this, it can possibly be intercropped with quick growing and short duration food grain, pulse and oilseed crops in appropriate geometry to exploit more yield and economics per unit area. Intercropping these crops may also be an option to the farmer to realize nutritive cereal, pulse or oilseed crop for the dietary requirement in addition to the cash crop of castor. Advantage of intercropping in castor can be increased by reorienting crop geometry for better availability of solar energy (Willey, 1979) and putting suitable intercrops. Legume crops may be better choice owing to beneficial effect of fixing atmospheric nitrogen and thereby some extra nitrogen was perhaps made available to the castor to utilize more efficiently beyond 90 DAS to harvest of castor. Crop geometry is an important factor to achieve higher production by better utilization of moisture and nutrients from the soil and with above soil by harvesting the maximum possible solar radiation and in turn better photosynthates formation (Thavaprakaashet al., 2005). By adopting appropriate crop geometry in the intercropping systems, the total productivity can be enhanced (Umraniet al., 1984). Looking to good proposal of castor in irrigated ecosystem of Southern-Western Haryana this was conducted to realize higher net return. In order to have best utilization of available resources, present study was planned with crop geometry and short duration intercrop between underutilized inter row space on account of initial slow growth of castor.

\section{Materials and Methods}

A field experiment was conducted during 2015-16 at Regional Research Station, Bawal (Rewari), CCS Haryana Agricultural University. The soil of the experimental field was loamy sand in texture and slightly alkaline in reaction $(\mathrm{pH} 8.5)$, low in organic carbon $(0.20 \%)$ and nitrogen $\left(148 \mathrm{~kg} \mathrm{ha}^{-1}\right)$, medium in available phosphorus (13.4 $\left.\mathrm{kg} \mathrm{ha}^{-1}\right)$ and potassium $\left(151 \mathrm{~kg} \mathrm{ha}^{-1}\right)$. The experiment was conducted in randomized block design with three replications. The intercropping system comprising, sole castor, castor + greengram, castor + sesamum, castor + groundnut and castor + clusterbean under three level of row spacing of castor, viz., 12,0 180 and $240 \mathrm{~cm}$ and fifteen treatment combinations were made viz., Sole castor (120 $\mathrm{cm})$, Castor $(120 \mathrm{~cm})$ + greengram (1:2), Castor $(120 \mathrm{~cm})+$ sesamum (1:2), Castor (120 $\mathrm{cm})+$ groundnut $(1: 2)$, Castor $(120 \mathrm{~cm})+$ clusterbean (1:2), Sole castor $(180 \mathrm{~cm})$, Castor $(180 \mathrm{~cm})+$ greengram $(1: 4)$, Castor $(180 \mathrm{~cm})$ + sesamum (1:4), Castor $(180 \mathrm{~cm})+$ groundnut (1:4), Castor $(180 \mathrm{~cm})+$ clusterbean (1:4), Sole castor $(240 \mathrm{~cm})$, Castor $(240 \mathrm{~cm})+$ greengram $(1: 6)$, Castor $(240 \mathrm{~cm})$ + sesamum (1:6), Castor $(240 \mathrm{~cm})+$ groundnut $(1: 6)$ and Castor $(240 \mathrm{~cm})+$ clusterbean (1:6).

Castor hybrid DCH-177, greengram var. Basanti, Groundnut var. MH-4, sesamum var. HT-1 and Clusterbean var. HG 2-20 were sown on 3 July. All intercrops are sown at 30 $\mathrm{cm} \times 10 \mathrm{~cm}$ row spacing. The recommended dose of $\mathrm{N}$ (40 kg ha ${ }^{-1}$ ), full dose of $\mathrm{P}_{2} \mathrm{O}_{5}(50$ $\mathrm{kg} \mathrm{ha}^{-1}$ ) and $\mathrm{K}_{2} \mathrm{O}\left(25 \mathrm{~kg} \mathrm{ha}^{-1}\right)$ was applied to castor through urea, DAP and MOP at the time of sowing by drilling in furrows $5-8 \mathrm{~cm}$ below the seeds. Remaining 50 per cent N (40 $\mathrm{kg} \mathrm{ha}^{-1}$ ) was top dressed in two equal splits at 
20 days crop growth stage and 30 days thereafter. Recommended dose of fertilizer for intercrops apply as per the package of CCSHAU, Hisar. In all the intercrops nitrogen was applied as top dressing. Castor was weeded manually twice 20 and 40 DAS. During the crop season there was $292.8 \mathrm{~mm}$ rainfall. In all these were 7 pickings 120,150 , 180, 210, 240, 270 and 300 days after sowing, respectively. All other intercultural practices were done as per package of practices. For oil extraction, one gm dried and grinded seed samples were treated with petroleum- ether for 1- 2 hours in Soxhlet apparatus. After oil extraction, the treated samples were dried and weighed. Per cent reduction in oil content was calculated using simple formula given below:

(Weight of sample before extraction Weight of sample after extraction) Oil content $(\%)=$

Weight of sample before extraction

Seed yield in each picking after threshing and winnowing was weighed. Seed weight of all pickings for each plot was summed to record yield in $\mathrm{kg} \mathrm{plot}^{-1}$. Finally plot yield was converted to $\mathrm{kg} \mathrm{ha}^{-1}$. For stover yield, plants were uprooted after last picking and kept for drying in the same plot. After satisfactory drying, the stalk was weighed and the weight was recorded in $\mathrm{kg} \mathrm{plot}^{-1}$ and subsequently converted to $\mathrm{kg} \mathrm{ha}^{-1}$. The weight of completely sun dried plants and total capsules weight in respective plots were added and expressed as biological yield in $\mathrm{kg} \mathrm{ha}^{-1}$.Castor equivalent yield (CEY) was calculated in terms of castor yield of all intercropping treatments on the basis of prevailing market prices $\left(\mathrm{Rs}^{\mathrm{kg}}{ }^{-1}\right)$. It was calculated using formula suggested by Lal and Ray (1976).

CEY $\left(\mathrm{Kg} \mathrm{ha}^{-1}\right)=[$ Seed yield of intercrops $(\mathrm{kg}$ $\left.\mathrm{ha}^{-1}\right) \mathrm{x}$ Price of intercrop $\left(\mathrm{Rs} \mathrm{kg}^{-1}\right) /$ Price of castor $\left.\left(\mathrm{Rs} \mathrm{kg}^{-1}\right)\right]+$ seed yield of castor $(\mathrm{kg}$ $\mathrm{ha}^{-1}$ )
All the experimental data were statistically analysed by usual method of 'Analysis of Variance as described by Gomez and Gomez (1984).

\section{Results and Discussion}

\section{Oil content and oil yield}

Experiment results revealed that different intercropping systems and row spacing of castor have no significant influence on oil content of castor. These findings are in accordance with the findings of Patel et al., (2007). Highest oil yield $\left(2554 \mathrm{~kg} \mathrm{ha}^{-1}\right)$ was recorded in sole castor $(120 \mathrm{~cm})$ followed by castor $(120 \mathrm{~cm})+$ greengram $(1: 2)$ intercropping system. Among row spacing of castor oil yield were declined 1.40 and 13.89 per cent in sole castor $(180 \mathrm{~cm})$ and sole castor $(240 \mathrm{~cm})$ over sole castor $(120 \mathrm{~cm})$, respectively. Among different intercropping systems higher oil yield of castor was recorded in castor + greengram intercropping due to higher seed yield of castor as compared to other intercropping systems. Similar result was also observed by Agarwal (2005) who reported that among different intercropping systems higher oil yield was obtained in castor + greengram intercropping system.

\section{Yields}

Sole castor recorded higher seed yield than intercropping system due to competition offered by these intercrops for natural resources The highest castor seed yield (5246 $\mathrm{kg} \mathrm{ha}^{-1}$ ) was obtained when castor crop was sown as sole castor $(120 \mathrm{~cm})$ though, it was found at par with sole castor $(180 \mathrm{~cm})$ and castor $(120 \mathrm{~cm})+$ greengram (1:2). Among different intercropping systems higher seed yield of castor was obtained in castor $(120 \mathrm{~cm})$ + greengram (1:2) followed by castor (120 $\mathrm{cm})+$ groundnut (1:2). A significant reduction in seed yield of castor was observed under 
intercropping treatments. The reduction in seed yield of castor, in the intercropping system was mainly due to reduction in plant stand of castor in different intercropping treatment replacement type of intercropping system was followed in the present study. Minimum magnitude of reduction in seed yield of castor was observed with greengram because greengram seems to be less harmful for castor might be due to its short life span and also their growth peaks are never coincide with each other which reduced demand pressure and environmental resources are efficiently utilized by both the crops. The magnitude of reduction in seed yield of castor was more severe with sesamum followed by clusterbean. Chand and Sujatha (2000) reported similar result that castor + sesamum intercropping recorded lower seed yield. The stalk yield of castor in sole planting at $240 \mathrm{~cm}$ and with 1:6 row combination with all the intercrops in this row spacing decreased significantly as compared to sole castor planted at $120 \mathrm{~cm}$ row spacing. Lowest stalk yield $\left(6565 \mathrm{~kg} \mathrm{ha}^{-1}\right)$ of castor was obtained in castor $(240 \mathrm{~cm})+$ clusterbean (1:6) intercropping system. The data (Table 1) showed that significantly higher stalk yield was recorded under sole castor $(120 \mathrm{~cm})$ which could be attributed to more number of plant population in sole castor $(120 \mathrm{~cm})$. Among intercropping highest biological yield $\left(12752 \mathrm{~kg} \mathrm{ha}^{-1}\right)$ of castor was recorded in castor $(120 \mathrm{~m})+$ greengram (1:2) and lowest $\left(10996 \mathrm{~kg} \mathrm{ha}^{-1}\right)$ in castor $(240 \mathrm{~cm})+$ clusterbean (1:6).

The data (Table 1) indicated that seed and stover yield of greengram, groundnut, clusterbean and sesamum were increased in $1: 4$ and $1: 6$ as compared to $1: 2$ row proportion due to higher plant densities of intercrops in 1:4 and 1:6 row ratio. Among the intercrops groundnut recorded higher grain yield of 1120 and $886 \mathrm{~kg} \mathrm{ha}^{-1}$ at 1:6 and 1:4 row proportion, respectively as compared to other intercrops.

Table.2 Effect of different treatments on economics of castor

\begin{tabular}{|c|c|c|c|c|c|}
\hline \multicolumn{2}{|c|}{ Treatments } & $\begin{array}{c}\text { Cost of } \\
\text { cultivation } \\
\left(\operatorname{Rs~ha} \mathbf{a}^{-1}\right)\end{array}$ & $\begin{array}{l}\text { Gross } \\
\text { return } \\
\text { (Rs/ha) }\end{array}$ & $\begin{array}{c}\text { Net } \\
\text { return } \\
\text { (Rs/ha) }\end{array}$ & $\begin{array}{l}\text { Benefit: } \\
\text { Cost ratio }\end{array}$ \\
\hline $\mathbf{T}_{1}$ & Sole castor $(120 \mathrm{~cm})$ & 70031 & 168666 & 98635 & 1.41 \\
\hline $\mathbf{T}_{2}$ & Castor $(120 \mathrm{~cm})+$ greengram $(1: 2)$ & 71786 & 191772 & 119986 & 1.67 \\
\hline $\mathbf{T}_{3}$ & Castor $(120 \mathrm{~cm})+$ sesamum $(1: 2)$ & 70839 & 168102 & 97263 & 1.37 \\
\hline $\mathbf{T}_{4}$ & Castor $(120 \mathrm{~cm})+$ groundnut $(1: 2)$ & 74092 & 185262 & 111170 & 1.50 \\
\hline $\mathbf{T}_{5}$ & Castor $(120 \mathrm{~cm})+$ clusterbean $(1: 2)$ & 71662 & 170597 & 98935 & 1.38 \\
\hline $\mathrm{T}_{6}$ & Sole castor $(180 \mathrm{~cm})$ & 69419 & 168593 & 99174 & 1.43 \\
\hline $\mathbf{T}_{7}$ & Castor $(180 \mathrm{~cm})+$ greengram $(1: 4)$ & 68604 & 188367 & 119763 & 1.75 \\
\hline $\mathbf{T}_{8}$ & Castor $(180 \mathrm{~cm})+$ sesamum $(1: 4)$ & 68419 & 171035 & 102616 & 1.50 \\
\hline $\mathbf{T}_{9}$ & Castor $(180 \mathrm{~cm})+$ groundnut $(1: 4)$ & 73318 & 192382 & 119064 & 1.62 \\
\hline $\mathbf{T}_{10}$ & Castor $(180 \mathrm{~cm}+$ clusterbean $(1: 4)$ & 70244 & 165327 & 95083 & 1.35 \\
\hline $\mathbf{T}_{11}$ & Sole castor $(240 \mathrm{~cm})$ & 68887 & 143234 & 74347 & 1.08 \\
\hline $\mathbf{T}_{12}$ & Castor $(240 \mathrm{~cm})+$ greengram $(1: 6)$ & 67979 & 189434 & 121455 & 1.79 \\
\hline $\mathbf{T}_{13}$ & Castor $(240 \mathrm{~cm})+$ sesamum $(1: 6)$ & 68707 & 150942 & 82235 & 1.20 \\
\hline $\mathbf{T}_{14}$ & Castor $(240 \mathrm{~cm})+$ groundnut $(1: 6)$ & 74053 & 186487 & 112434 & 1.52 \\
\hline $\mathbf{T}_{15}$ & Castor $(240 \mathrm{~cm})+$ clusterbean $(1: 6)$ & 69469 & 158054 & 88585 & 1.28 \\
\hline
\end{tabular}


Table.1 Effect of different treatments on oil content and yield of castor

\begin{tabular}{|c|c|c|c|c|c|c|c|c|c|c|}
\hline & Treatments & $\begin{array}{l}\text { Oil } \\
\text { content }\end{array}$ & $\begin{array}{l}\text { Oil yield } \\
(\mathrm{kg} / \mathrm{ha})^{1}\end{array}$ & Seed yi & dd (kg/ha) & $\begin{array}{r}\text { Stalk/S } \\
(\mathrm{k}\end{array}$ & $\begin{array}{l}\text { over yield } \\
\text { g/ha) }\end{array}$ & $\begin{array}{r}\text { Biolog } \\
\quad(\mathrm{k}\end{array}$ & $\begin{array}{l}\text { ical yield } \\
\text { /ha) }\end{array}$ & $\begin{array}{c}\text { Castor } \\
\text { equivalent }\end{array}$ \\
\hline & & & & Castor & Intercrop & Castor & Intercrop & Castor & Intercrop & (kg/ha) \\
\hline $\mathbf{T}_{1}$ & Sole castor $(120 \mathrm{~cm})$ & 48.67 & 2554 & 5246 & & 7721 & & 12967 & & 5246 \\
\hline $\mathbf{T}_{2}$ & Castor $(120 \mathrm{~cm})+$ greengram $(1: 2)$ & 49.10 & 2524 & 5140 & 420 & 7612 & 1156 & 12752 & 1576 & 6026 \\
\hline$\overline{T_{3}}$ & Castor $(120 \mathrm{~cm})+$ sesamum $(1: 2)$ & 48.90 & 2438 & 4987 & 155 & 7441 & 486 & 12427 & 641 & 5287 \\
\hline$T_{4}$ & Castor $(120 \mathrm{~cm})+$ groundnut $(1: 2)$ & 48.60 & 2455 & 5053 & 636 & 7429 & 1354 & 12482 & 1991 & 5813 \\
\hline$T_{5}$ & $\begin{array}{l}\text { Castor }(120 \mathrm{~cm})+\text { clusterbean } \\
(1: 2)\end{array}$ & 48.47 & 2434 & 5020 & 280 & 7190 & 861 & 12210 & 1141 & 5359 \\
\hline$T_{6}$ & Sole castor $(180 \mathrm{~cm})$ & 48.73 & 2518 & 5163 & & 7552 & & 12715 & & 5163 \\
\hline $\mathbf{T}_{7}$ & $\begin{array}{l}\text { Castor }(180 \mathrm{~cm})+\text { greengram } \\
(1: 4)\end{array}$ & 47.10 & 2314 & 4913 & 580 & 7267 & 1617 & 12180 & 2197 & 5907 \\
\hline$T_{8}$ & Castor $(180 \mathrm{~cm})+$ sesamum $(1: 4)$ & 47.87 & 2301 & 4807 & 330 & 7129 & 1035 & 11935 & 1365 & 5307 \\
\hline $\mathbf{T}_{9}$ & Castor $(180 \mathrm{~cm})+$ groundnut $(1: 4)$ & 48.10 & 2358 & 4898 & 886 & 7395 & 1529 & 12293 & 2416 & 6037 \\
\hline $\mathbf{T}_{10}$ & Castor $(180 \mathrm{~cm}+$ clusterbean $(1: 4)$ & 48.47 & 2354 & 4859 & 368 & 7239 & 1191 & 12098 & 1560 & 5180 \\
\hline $\mathbf{T}_{11}$ & Sole castor $(240 \mathrm{~cm})$ & 48.70 & 2199 & 4515 & & 6745 & & 11260 & & 4515 \\
\hline $\mathbf{T}_{12}$ & $\begin{array}{l}\text { Castor }(240 \mathrm{~cm})+\text { greengram } \\
(1: 6)\end{array}$ & 48.03 & 2192 & 4567 & 720 & 6824 & 2103 & 11390 & 2823 & 5933 \\
\hline $\mathbf{T}_{13}$ & Castor $(240 \mathrm{~cm})+$ sesamum $(1: 6)$ & 47.90 & 2082 & 4350 & 421 & 6652 & 1379 & 11002 & 1800 & 4717 \\
\hline $\mathbf{T}_{14}$ & Castor $(240 \mathrm{~cm})+$ groundnut $(1: 6)$ & 48.57 & 2203 & 4533 & 1120 & 6821 & 2410 & 11354 & 3530 & 5828 \\
\hline $\mathbf{T}_{15}$ & $\begin{array}{l}\text { Castor }(240 \mathrm{~cm})+\text { clusterbean } \\
(1: 6)\end{array}$ & 47.30 & 2082 & 4401 & 688 & 6565 & 2287 & 10966 & 2976 & 4919 \\
\hline & SEm \pm & 0.43 & 87.23 & 173 & 55 & 329 & 186 & 318 & 234 & 267 \\
\hline & C.D. $(\mathrm{P}=0.05)$ & NS & 247.25 & 490 & 163 & 678 & 549 & 853 & 690 & 526 \\
\hline
\end{tabular}


In all three row proportion lowest yield was obtained in sesamum compared to other intercrops. Agarwal (2005) also obtained similar result that sesamum recorded lowest yield than other intercrops greengram, blackgram and clusterbean. Among the intercrops groundnut recorded higher biological yield of 3530 and $2416 \mathrm{~kg} \mathrm{ha}^{-1}$ at 1:6 and 1:4 rows proportion, respectively as compared to other intercrops. Groundnut recorded significantly higher stover yield $\left(3530 \mathrm{~kg} \mathrm{ha}^{-1}\right)$ at $1: 6$ row proportion though, it was found at par with the castor $(240 \mathrm{~cm})+$ clusterbean $(1: 6)$.

Although significant reduction in the seed yield of base crop and intercrops in different intercropping treatments was recorded, yet the recovery in the seed yield in treatment like castor + groundnut (1:4) and castor + greengram (1:2) was higher which leads to higher castor equivalent yield than sole castor. Castor equivalent yield was significantly higher in castor + groundnut (1:4) and castor+ greengram (1:2) over sole castor and other intercropping systems which might be due to higher yield of groundnut and greengram as well as less reduction of castor seed yield in this intercropping system. Similar results reported by Dhimmar (2009) that castor + greengram intercropping system recorded highest castor equivalent yield. Higher castor equivalent yield under castor + legume intercropping system over sole castor and castor + sesamum. These results are in conformity with the earlier findings of Sharma and Singh (2014).

\section{Economics}

Highest gross return was obtained in castor $(180 \mathrm{~cm})+$ groundnut $(1: 4)$ followed by castor $(120 \mathrm{~cm})+$ greengram $(1: 2)$. The monetary return as elucidated by net return was significantly higher in intercropping as compared to sole castor (Table 2). Looking to the economics, castor + greengram (1:6) and castor + greengram (1:2) gave higher net realization than other intercropping system and sole castor. This could be due to higher yield of castor as well as intercrops in intercropping systems. Castor + greengram (1:6) intercropping system gave highest net return (Rs. $121455 \mathrm{ha}^{-1}$ ) due to higher yield of greengram as well as less reduction in seed yield of castor. Intercropping of sesamum and clusterbean reported lower seed yield of castor because it might suppressed the growth of castor and reduced the yield of castor and ultimately monetary return was decreased as compared to other intercropping systems and their sole crops. Rajput and Shrivastava (1996) reported that adoption of castor + sesamum intercropping system reduced the net returns. Castor $(240 \mathrm{~cm})+$ greengram (1:6) intercropping provided 23.13, 22.46 and 63.36 per cent higher net return over sole castor $(120 \mathrm{~cm})$, sole castor $(180 \mathrm{~cm})$ and sole castor $(240 \mathrm{~cm})$, respectively. Highest B: C ratio (1.79) was obtained in castor $(240 \mathrm{~cm})+$ greengram $(1: 6)$ followed by castor $(180 \mathrm{~cm})$ + greengram (1:4) with B: C ratio of (1.75)

Based on the results it can be concluded that intercropping of castor $(240 \mathrm{~cm})+$ greengram at 1:6 row ratio was distinctly superior over sole castor and found more profitable by realizing the net return of Rs. $121455 \mathrm{ha}^{-1}$ and benefit cost ratio of 1.79 on loamy sand soils of Bawal (Rewari) under Southern-Western Haryana conditions.

\section{References}

Agarwal, S. K. 2005. Effect of planting methods and intercropping on the productivity of castor (Ricinus communis L.) under irrigated ecosystem. Ph.D. Thesis Submitted to MPUAT, Udaipur.

Anonymous. 2015. http//www.indiastate.com/agriculture/2. 
Chand, P. and Sujatha, M. 2000. Castor based intercropping systems- a review. Agricultural. Reviews, 21(4): 244-248.

Dhimmar, S. K. 2009. Effect on growth and yield of rabi castor in pulses intercropping under varying planting geometry. American-Eurasian Journal of Scientific Research, 4 (3): 165-168.

Lal, R. B. and Ray, S. 1976. Economics of different cropping intensities. Indian Journal of AgriculturalScience, 46: 9396.

Patel, K.S., Patel, M.K., Patel, G.N. and Pathak, H.C. 2007. Intercropping in castor (RicinuscommunisL.) under irrigated condition. Journal of Oilseeds Research, 24(1): 121-123.

Rajput, R. I. and Shrivastava, U. K. 1996. Performance of castor (Ricinus communis L.) based intercropping under rainfed condition. Indian Journal of Agronomy, 41(4): 550-552.

Sharma, S. K. and Singh, J. 2014. Productivity and economics of castor (Ricinuscommunis) based intercropping systems under rainfed conditions. Indian Journal of Agricultural Sciences, 84 (3): 432-435.

Thavaprakaash, N., K. Velayudham and V.B. Muthukumar. 2005b. Effect of crop geometry, intercropping systems and integrated nutrient management practices on productivity of baby corn (Zea mays L.) based inter cropping system Research Journal of Agricultural and Biological Sciences, 1(4): 295-302.

Willey, R. W. 1979. Intercropping-its importance and research needs. Part - I. Competition and yield advantages. Field crop Abstract, 32(1): 1-10.

\section{How to cite this article:}

Mohammed Mohsin, J.S. Yadav, Harender and Naveen Rathi. 2018. Effect of Castor Based Intercropping Systems on Yields and Economics of Castor (Ricinus communis L.).Int.J.Curr.Microbiol.App.Sci.7(10): 3014-3020. doi: https://doi.org/10.20546/ijcmas.2018.710.351 